Acta Protozool. (2017) 56: 211-216

www.ejournals.eu/Acta-Protozoologica

doi:10.4467/16890027AP.17.018.7499

PROTOZOOLOGICA

Short communication

\title{
Testate Amoeba Diversity of a Poor Fen on Mineral Soil in the Hilly Area of Central Honshu, Japan
}

\author{
Satoshi D. SHIMANO ${ }^{1}$, Anatoly BOBROV ${ }^{2}$, Manfred WANNER ${ }^{3}$, Mariusz LAMENTOWICZ ${ }^{4}$, \\ Yuri MAZEI ${ }^{5}$, Taisuke OHTSUKA ${ }^{6}$ \\ ${ }^{1}$ Hosei University, Fujimi, Chiyoda, Tokyo, Japan; ${ }^{2}$ Department of Soil Geography, Faculty of Soil Science, Lomonosov Moscow \\ State University, Moscow, Russia; ${ }^{3}$ Brandenburg University of Technology Cottbus-Senftenberg, Department of Ecology, Cottbus, \\ Germany; ${ }^{4}$ Laboratory of Wetland Ecology and Monitoring, Faculty of Geographical and Geological Sciences, Adam Mickiewicz \\ University, Poznań, Poland; Department of Biogeography and Paleoecology, Adam Mickiewicz University, Poznań, Poland; \\ ${ }^{5}$ Department of Hydrobiology, Faculty of Biology, Lomonosov Moscow State University, Moscow, Russia; Department of Zoology \\ and Ecology, Penza State University, Penza, Russia; ${ }^{6}$ Research Division, Lake Biwa Museum, Shiga, Japan
}

\begin{abstract}
We present a short note on the species composition of testate amoebae in a poor fen on mineral soil near the Pacific Coast in the hilly area of Central Honshu, Japan. In total 45 species and subspecific taxa belonged to 21 genera and 14 families of testate amoebae were recorded. Eight species and nine subspecies are newly recorded from Japan. However, most species from the list can be considered as distributed worldwide and associated mostly to oligotrophic/acid Sphagnum conditions.
\end{abstract}

Keywords: testate amoebae, mineral soil, fen, Japan, Sphagnum, Rhizaria, Amoebozoa, Stramenopiles.

\section{INTRODUCTION}

Peatland scientists have paid relatively little attention to poor fens, especially in Asian countries. Poor fens are peatlands in which the vegetation is fed by rain as well as minerotrophic water (surface- or ground-water-fed), the water possesses a low $\mathrm{pH}$ and is poor in nutrients (Rydin and Jeglum 2006). Vegetation of poor fens consists of vascular plants (e.g. Carex spp.) and Sphagnum spp. In Central to Western Honshu, Japan, peat mosses (Sphagnum spp.) usually occur on mineral

Address for correspondence: Satoshi D. Shimano, Hosei University, Fujimi, Chiyoda, Tokyo, 102-8160 Japan; E-mail: sim@hosei.ac.jp soil with little or no peat accumulation. Such fens, usually dominated by Rhynchospora spp., Eriocaulon spp. and Utricularia spp., are defined as wet grasslands on mineral soil (Hada 1984; Tomita 2010).

Testate amoeba assemblages on Sphagnum have been well studied in bogs (e.g., Jassey et al. 2012; Lamentowicz et al. 2013; Qin et al. 2013; Marcisz et al. 2014; Amesbury et al. 2016) and minerotrophic peatlands (e.g. Lamentowicz et al. 2010, 2011; Jassey et al. 2014), but there appear not to be any studies of the testate amoebae of Sphagnum fens on mineral soil, probably because this kind of habitat is rare in Europe or other parts of the world.

This is the first report of a testate amoeba assemblage on Sphagnum in a hillside-slope type poor fen 
developed on mineral soil. We aim to contribute to the general understanding of such ecosystems, which have been neglected but are not rare in Central to Western Honshu. Our study is also the next step towards a better understanding of the biogeography of testate amoebae.

\section{MATERIALS AND METHODS}

The sampling site is a slope type of a poor fen dominated by Sphagnum palustre among an open forest of Cryptomeria japonica (Thunb. ex L.f.) D.Don, located in Koka City, Shiga prefecture in
West-Central Honshu, Japan $\left(34.917^{\circ} \mathrm{N}, 136.083^{\circ} \mathrm{E}\right)$, at an altitude of $281 \mathrm{~m}$ (Fig. 1). The samples were collected on 20 February, 2012 by S.D. Shimano. Three samples of the Sphagnum moss of the uppermost $5 \mathrm{~cm}$ were sampled in several points of the fen placed 3 meters apart from each other. Testate amoebae were extracted from a $5 \mathrm{~cm}^{3}$ quota taken from each sample irrespectively of the nature of the habitat. Samples for the analysis were prepared using a method based on wet sieving. $1 \mathrm{~cm}^{3}$ of the sample was soaked in water for 24 hours, stirred, filtered at $0.5 \mathrm{~mm}$, the suspension left to settle for a further 24 hours, and the supernatant decanted off following Mazei and Chernyshov (2011). The specimens were studied using light microscopy. The higher taxa of testate amoeba were arranged according to Meisterfeld (2000a, 2000b), Adl et al. (2012) and Siemensma (2016) and annotations based on Shimano and Miyoshi (2008) were

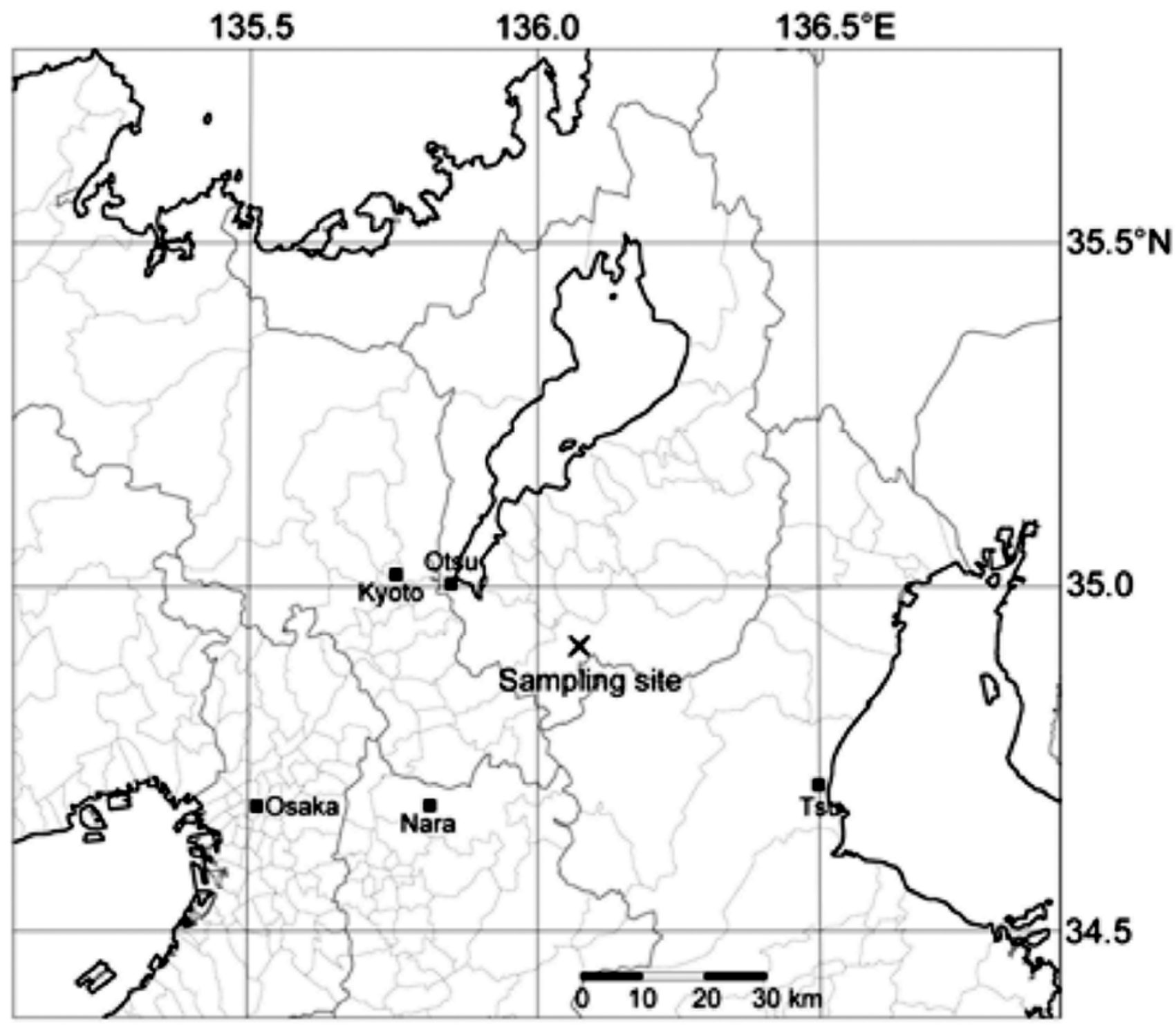

Fig. 1. Location of the poor fen on mineral soil as sampling site $(\times)$. 
added to species list. A species accumulation curve was constructed based on rarefaction procedure performed in PRIMER 6.1.6 (Clarke and Gorley, 2006). The maximum expected number of species was calculated in PRIMER 6.1.6 by the nonparametric Chao2 method, which takes into consideration the theoretical number of expected rare species (Clarke and Warwick 2001).

\section{RESULTS}

In totally 45 species and subspecific taxa from 21 genera, 14 families of testate amoebae were recorded. 8 species and 9 subspecific taxa are newly recorded from Japan (Table 1).

The results of a rarefaction procedure show that the species-accumulation curve does not reach a plateau (Fig. 2). The curve is well fitted $\left(\mathrm{R}^{2}=0.99\right)$ by the power function $S=22.52 N^{0.67}$ (where $S$ is number of species revealed, $N$ is number of samples investigated). A low value of the power coefficient (0.67) reflects an unsaturated community with 22.52 as an average number of taxa per sample. Expected total number of species (Chao2) in the studied area is estimated as 72.

\section{DISCUSSION}

Among the different types of poor fens on mineral soil, a "soligenous sloping fen" is frequently observed that develops on a slope watered by a divergent flow of water seeping from the upper part of the slope (Lamentowicz et al. 2010; Tomita 2010). Such fens are usu-

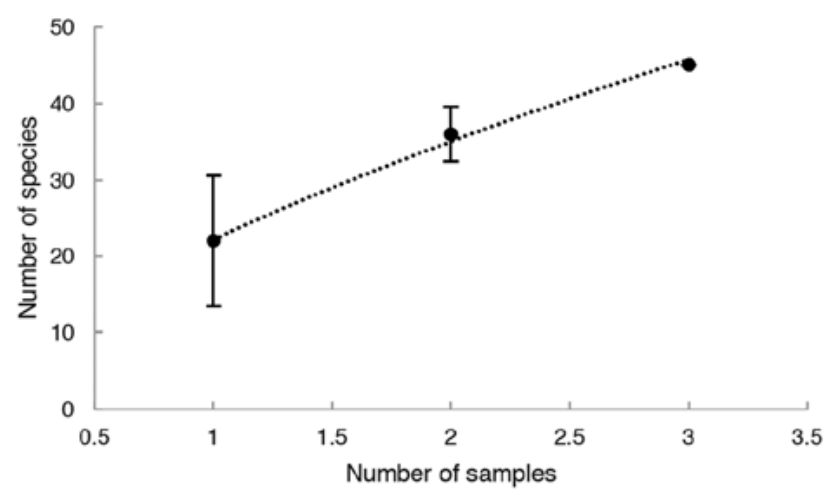

Fig. 2. Sample-based testate amoeba species accumulation curve for all three samples collected in the sampling site of the poor fen on mineral soil. The bars are standard deviations. ally situated atop granite or rhyolite (Hada 1984; Tomita 2010), and their vegetation is often dominated by Sphagnum palustre L., despite they are not exclusively ombrotrophic (rain-fed) and strongly acidic conditions typical of Sphagnum bogs under open forest of Japanese cedar Cryptomeria japonica (Thunb. ex L.f.) D.Don. Such fens appear not to be covered by the classification system of wetlands developed in Europe (cf. Succow and Jeschke 1986; Rydin and Jeglum 2006; Hotes 2007).

Based only on three samples from one sampling date, already 45 taxa of testate amoebae were found, of which 17 taxa are new records for Japan. This finding reveals an unexpected high diversity for this type of poor fen from Japan. A study conducted in several Sphagnum-dominated peatlands from north-western Poland revealed 52 species from 44 samples (Lamentowicz and Mitchell 2005).

Most of the species represent acidic conditions of a Sphagnum bog. The testate amoebae species composition resembles a typical ombrotrophic bog, despite they are located in the mesotrophic conditions. There are mixotrophic species present such as Hyalosphenia papilio, representing more open parts of the Sphagnum patches (Payne et al. 2016). There were no clear indicators of a rich fen, so we can assume that the habitat is generally poor in nutrients, although Centropyxis spp. might represent a higher nutrient status. As this issue is very interesting, our next study will better characterize community structure and abundance of each species.

In the present study, all determined genera and almost all species are characterized by uniquely defined tests, thus a misidentification can be excluded. However, Valkanovia elegans cannot be distinguished from Assulina muscorum (type 4), but Valkanovia can inhabit both upper and lower horizons, whereas Assulina and its forms lives exclusively in the upper horizon layer (Schönborn and Peschke 1990). All species from the list can be considered as cosmopolitan. Most likely, this fact reflects a low level of local geographic specificity for such non-zonal ecosystems like peatlands. On the opposite, in soils of zonal ecosystems in the Imperial Palace area, Tokyo, Shimano et al. (2014) found two species with limited geographical distribution (Centropyxis latideflandriana and Planhoogenraadia daurica), thus more species with geographical limitation can be expected for the future in Japan. Moreover, there will be a considerable amount of new or unrecorded testate amoeba taxa for Japan, the assumption is borne out by recent research papers (Aoki et al. 2007; Bobrov 
Table 1. List of taxa from the Tokai Hilly Land Spring-fed Mires (* - new to Japan).

AMOEBOZOA Lühe, 1913 emend. Cavalier-Smith, 1998 ORDER ARCELLINIDA Kent, 1880

FAMILY ARCELLIDAE Ehrenberg, 1843

Genus Arcella Ehrenberg, 1832

1. Arcella discoides Ehrenberg, 1871

2. Arcella discoides foveosa Playfair, 1918 *

3. Arcella sp.

FAMILY DIFFLUGIIDAE Wallich, 1864

Genus Difflugia Leclerc, 1815

4. Difflugia bacillifera Pénard, 1890

5. Difflugia globulosa Dujardin, 1837

6. Difflugia globulus (Ehrenberg, 1848)

7. Difflugia oblonga Ehrenberg, 1838

Genus Wailesella Deflandre, 1928

8. Wailesella eboracensis (Wailes and Pénard, 1911) Deflandre, 1928

FAMILY CENTROPYXIDAE Jung, 1942

Genus Centropyxis Stein, 1857

9. Centropyxis aculeata (Ehrenberg, 1838) Stein, 1857

10. Centropyxis aculeata dentistoma Decloître, 1949 *

11. Centropyxis aculeata minima van Oye, $1938 *$

12. Centropyxis constricta (Ehrenberg, 1843) Deflandre, 1929

13. Centropyxis sylvatica (Deflandre, 1929) Bonnet \& Thomas, 1955

FAMILY PLAGIOPYXIDAE Bonnet and Thomas, 1960

Genus Bullinularia Deflandre, 1953

14. Bullinularia indica (Pénard, 1907) Deflandre, 1953 *

FAMILY HYALOSPHENIIDAE Schultze, 1877

Genus Hyalosphenia Stein, 1859

15. Hyalosphenia insecta Harnisch, 1938 *

16. Hyalosphenia papilio (Leidy, 1874) Leidy, 1879

FAMILY HELEOPERIDAE Jung, 1942

Genus Heleopera Leidy, 1879

17. Heleopera petricola amethystea Pénard, $1899 *$

18. Heleopera rectangularis Bonnet, 1966 *

FAMILY NEBELIDAE Taránek, 1882

Genus Nebela Leidy, 1874

19. Nebela barbata (Leidy, 1874)

20. Nebela marginata Pénard, $1902 *$

21. Nebela parvula Cash, 1909

22. Nebela sp. 1

Genus Porosia Jung, 1942

23. Porosia biggibosa (Pénard, 1890) Jung, 1942

Genus Argynnia Vucetich, 1974

24. Argynnia sp.

Genus Physochila Jung, 1942

25. Physochila griseola (Pénard, 1911) Jung, 1942

FAMILY CRYPTODIFFLUGIIDAE Jung, 1942

Genus Cryptodifflugia Pénard, 1890

26. Cryptodifflugia oviformis Pénard, 1890

27. Cryptodifflugia oviformis fusca Bonnet \& Thomas, 1955 *

FAMILY PHRYGANELLIDAE Jung, 1942

Genus Phryganella Pénard, 1902

28. Phryganella acropodia australica Playfair, 1917 *
RHIZARIA Cavalier-Smith, 2002

ORDER EUGLYPHIDA Copeland, 1956

FAMILY EUGLYPHIDAE Wallich, 1864

Genus Euglypha Dujardin, 1841

29. Euglypha compressa glabra Cash, Wailes \& Hopkinson, 1915 *

30. Euglypha cuspidata Bonnet, 1959 *

31. Euglypha laevis Perty, 1849

32. Euglypha tuberculata Durjardin, 1841

FAMILY ASSULINIDAE Lara et al., 2007

Genus Assulina Leidy, 1879

33. Assulina muscorum Greeff, 1889

34. Assulina seminulum (Ehrenberg, 1848) Leidy, 1879

35. Assulina scandinavica Pénard, 1890 *

Genus Placocista Leidy, 1879

36. Placocista spinosa (Carter, 1865) Leidy, 1879

Genus Valkanovia Tappan, 1966

37. Valkanovia elegans (Schönborn, 1964) Tappan, 1966

FAMILY SPHENODERIIDAE Chatelain et al., 2013

Genus Sphenoderia Schlumberger, 1845

38. Sphenoderia splendida (Playfair, 1918)

FAMILY TRINEMATIDAE Hoogenraad \& de Groot, 1940

Genus Trinema Dujardin, 1841

39. Trinema complanatum Pénard, 1890

40. Trinema lineare Pénard, 1890

41. Trinema lineare minuscula Chardez, 1971 *

Genus Corythion Taránek, 1881

42. Corythion dubium Taránek, 1882

43. Corythion dubium orbicularis Pénard, $1911 *$

44. Trachelocorythion pulchellum (Pénard, 1890) Bonnet, 1979 *

STRAMENOPILES Patterson 1989, emend. Adl et al. 2005

ORDER AMPHITREMIDA Poche1913

FAMILY AMPHITREMIDAE Poche, 1913

Genus Amphitrema Archer, 1869

45. Amphitrema wrigthianum Archer, 1869 
et al. 2012; Shimano et al. 2014; Bobrov and Kosakyan 2015) and bibliographies (Shimano and Miyoshi 2008). These few studies already resulted in more than 350 species, including three species new for science (Bobrov et al. 2012; Bobrov and Kosakyan 2015).

In Supplemental Table A, some environmental data are given. $\mathrm{pH}$ as a major environmental factor is still in the range as discussed by Lamentowicz and Mitchell (2005).

Acknowledgements. We thank Dr. Ralf Meisterfeld (Institute of Biology II (Zoology) RWTH Aachen) for his valuable comments. This research was partly supported by the JSPS KAKENHI (grant number $15 \mathrm{H} 02858$ ) to SS \& TO, by the JSPS (grant number S16738) to MW, the grant of the Russian Science Foundation (14-14-00891), the grant of the President of Russian Federation (MD-7930.2016.4) to YuM and RFBR (grant numbers 152902518 and 160400451) to AB.

\section{REFERENCES}

Adl S. M., Simpson A. G. B., Lane C. E., Lukeš J., Bass D., Bowser S. S., Brown M. W., Burki F., Dunthorn M., Hampl V., Heiss A., Hoppenrath M., Lara E., le Gall L,. Lynn D. H., McManus H., Mitchell E. A. D., Mozley-Stanridge S. E., Parfrey L. W., Pawlowski J., Rueckert S., Shadwick L., Schoch C. L., Smirnov A., Spiegel F. W., (2012) The revised classification of eukaryotes J. Eukaryot. Microbiol. 59: 429-493

Amesbury M. J., Swindles G. T., Bobrov A., Charman D. J., Holden J., Lamentowicz M., Mallon G., Mazei Y., Mitchell E. A. D., Payne R. J., Roland T. P., Turner T. E., Warner B. G. (2016) Development of a new pan-European testate amoeba transfer function for reconstructing peatland palaeohydrology. Quaternary Sci. Rev. 152: 132-151

Aoki Y., Hoshino M., Matsubara T. (2007) Silica and testate amoebae in a soil under pine-oak forest. Geoderma 142: 29-35

Bobrov A., Kosakyan A. (2015) A new species from mountain forest soils in Japan: Porosia paracarinata sp. nov., and taxonomic concept of the genus Porosia Jung, 1942. Acta Protozool. 54: 289-294

Bobrov A., Shimano S., Mazei Y. (2012) Two new species of testate amoebae from the mountain forests soils of Japan and redescription of the genus Deharvengia Bonnet, 1979. Acta Protozool. 51: $55-63$

Clarke K., Gorley R. (2006) PRIMER v. 6: User Manual/Tutorial. Plymouth.

Clarke K., Warwick R. (2001) Change in Marine Communities: An approach to statistical analysis and Interpretation, 2nd ed. Plymouth.

Hada Y. (1984) Phytosociological studies on the moor vegetation in the Chugoku District, S.W. Honshu, Japan. Bull. Hiruzen Res. Inst. 10: 73-110

Hotes S. (2007) Shitsugen seitaikei no tayosei - sono bunrui to hozen saisei (Diversity of wetland ecosystems - classification, conservation and restoration). Chikyu Kankyo 12: 21-36 (In Japanese)

Jassey V. E., Shimano S., Dupuy C., Toussaint M. L., Gilbert D. (2012) Characterizing the feeding habits of the testate amoebae Hyalosphenia papilio and Nebela tincta along a narrow "fen- bog" gradient using digestive vacuole content and ${ }^{13} \mathrm{C}$ and ${ }^{15} \mathrm{~N}$ isotopic analyses. Protist 163: 451-464

Jassey V. E., Lamentowicz Ł., Robroek B. J., Gąbka M., Rusińska A., Lamentowicz M. (2014) Plant functional diversity drives niche-size-structure of dominant microbial consumers along a poor to extremely rich fen gradient. J. Ecol. 102: 1150-1162

Lamentowicz M., Bragazza L., Buttler A., Jassey V. E. J., Mitchell E. A. D. (2013) Seasonal patterns of testate amoeba diversity, community structure and species-environment relationships in four Sphagnum-dominated peatlands along a $1300 \mathrm{~m}$ altitudinal gradient in Switzerland. Soil Biol. Biochem. 67: 1-11

Lamentowicz Ł., Gąbka M., Rusińska A., Sobczyński T., Owsianny P. M., Lamentowicz M. (2011) Testate amoeba (Arcellinida, Euglyphida) ecology along a poor-rich gradient in fens of Western Poland. Internat. Rev. Hydrobiol. 96: 356-380

Lamentowicz M., Lamentowicz Ł., van der Knaap W. O., Gąbka M., Mitchell E. A. D. (2010) Contrasting species - environment relationships in communities of testate amoebae, bryophytes and vascular plants along the fen-bog gradient. Microbial Ecol. 59: $499-510$

Lamentowicz M., Mitchell E. A. D. (2005) The ecology of testate amoebae (protists) in Sphagnum in north-western Poland in relation to peatland ecology. Microbial Ecol. 50: 48-63

Marcisz K., Fournier B., Gilbert D., Lamentowicz M., Mitchell E. A. D. (2014) Response of Sphagnum peatland testate amoebae to a 1-year transplantation experiment along an artificial hydrological gradient. Microbial Ecol. 67: 810-818

Mazei Yu., Chernyshov V. A. (2011) Testate amoebae communities in the southern tundra and forest-tundra of Western Siberia. Biol. Bull. 38: 789-796

Meisterfeld R. (2000a) Order Arcellinida Kent, 1880. In: The Illustrated Guide to the Protozoa vol. 2, 2nd ed, (Eds. J. J. Lee, G. F. Leedale, P. Bradbury). Allen press Inc, Kansas, USA, 827-860

Meisterfeld R. (2000b) Testate amoebae with filopodia. In: The Illustrated Guide to the Protozoa vol. 2, 2nd ed, (Eds. J. J. Lee, G. F. Leedale, P. Bradbury). Allen press Inc, Kansas, USA, $1054-1084$

Payne R., Greevy A., Malysheva E., Ratcliffe J., Andersen R., Tsyganov A., Rowson J., Marcisz K., Zielinska M., Lamentowicz M., Lapshina E., Mazei Yu. (2016) Tree encroachment may lead to functionally-significant changes in peatland testate amoeba communities. Soil Biol. Biochem. 98: 18-21

Rydin H., Jeglum J. (2006) The biology of peatlands. Oxford University Press.

Qin Y. M, Mitchell E. A. D., Lamentowicz M., Payne R. J., Lara E., Gu Y. S., Huang X. Y., Wang H. M. (2013) Ecology of testate amoebae in peatlands of central China and development of a transfer function for palaeohydrological reconstruction. $\mathrm{J}$. $\mathrm{Pa}$ leolimnol. 50: $319-330$

Schönborn W., Peschke T. (1990) Evolutionary studies on the Assulina-Valkanovia complex (Rhizopoda, Testaceafilosia) in Sphagnum and soil. Biol. Fertil. Soil 9: 95-100

Shimano S., Miyoshi N. (2008) A bibliography of publications on free-living protists (ciliates and testate amoebae) recorded from Japan - preliminary version, April 2008. Jpn J. Protozool. 41: 133-152 (In Japanese) (Updated version May, 2010: https:// sites.google.com/site/bibliographyjapan)

Shimano S., Bobrov A., Mazei Y. (2014) Testate amoebae of the Imperial Palace. Tokyo Mem. Natl. Mus. Nat. Sci. Tokyo 50: 21-28

Siemensma F. J. (2016) Microworld, world of amoeboid organisms. World-wide electronic publication, Kortenhoef, the Netherlands. http://www.arcella.nl. (Updated version on Oct. 28, 2016) 


\section{S. D. Shimano et al.}

Succow M., Jeschke L. (ed) (1986) Moore in der Landschaft - Entstehung, Haushalt, Lebewelt, Verbreitung, Nutzung und Erhaltung der Moore. URANIA Verlag Leipzig, Jena, Berlin

Tomita K. (2010) Distribution, formation, and classification of wet grassland on mineral soils in Japan. Wetland Res. 1: 67-86 (In Japanese)

Received on $6^{\text {th }}$ July, 2017; revised on $7^{\text {th }}$ October, 2017; accepted $10^{\text {th }}$ October, 2017

Supplemental Table. A list of data of the water sample and environments, collected in the sampling site of the Tokai Hilly Land Spring-fed Mires

\begin{tabular}{|c|c|}
\hline Environmental factors & value \\
\hline Water temperature ${ }^{\circ} \mathrm{C}$ & 8.0 \\
\hline $\mathrm{pH}$ & 5.7 \\
\hline $\mathrm{EC} \mathrm{mS/m}$ & 2.5 \\
\hline $\mathrm{NH}_{4}-\mathrm{N} \mu \mathrm{M}$ & 0.54 \\
\hline $\mathrm{NO}_{2}-\mathrm{N} \mu \mathrm{M}$ & 0.20 \\
\hline $\mathrm{NO}_{3}-\mathrm{N} \mu \mathrm{M}$ & 6.07 \\
\hline $\mathrm{PO}_{4}-\mathrm{P} \mu \mathrm{M}$ & 0.02 \\
\hline $\mathrm{TDN} \mu \mathrm{M}$ & 13.09 \\
\hline $\mathrm{TDP} \mu \mathrm{M}$ & 0.10 \\
\hline $\mathrm{Si} \mathrm{mg/L}$ & 3.693 \\
\hline $\mathrm{F} \mathrm{mg/L}$ & N.D. \\
\hline $\mathrm{Cl} \mathrm{mg/L}$ & 1.576 \\
\hline $\mathrm{Br} \mathrm{mg} / \mathrm{L}$ & N.D. \\
\hline $\mathrm{SO}_{4} \mathrm{mg} / \mathrm{L}$ & 1.498 \\
\hline $\mathrm{Li} \mathrm{mg/L}$ & 0.008 \\
\hline $\mathrm{Na} \mathrm{mg/L}$ & 1.087 \\
\hline $\mathrm{K} \mathrm{mg} / \mathrm{L}$ & 0.380 \\
\hline $\mathrm{Mg} \mathrm{mg} / \mathrm{L}$ & 0.038 \\
\hline $\mathrm{Mn} \mathrm{mg} / \mathrm{L}$ & N.D. \\
\hline $\mathrm{Ca} \mathrm{mg/L}$ & 0.043 \\
\hline
\end{tabular}

Electric conductivity (EC) and $\mathrm{pH}$ were checked at site with a B-173 conductivity meter (Horiba, Kyoto, Japan) and a B-212 pH meter (Horiba, Kyoto, Japan), respectively. Water temperature was measured with an alcohol thermometer. Water samples for water analyses in the laboratory were filtered by syringe-driven filter units with $0.22 \mu \mathrm{m}$ pore size hydrophilic Polyethersulfone (PES) membrane. Each water sample was partly kept in a refrigerator (for SRSi determination) and the rest in a freezer (for the other analyses). In the laboratory, major anions and cations were analyzed by ion column chromatography (DX-AQ: Nippon Dionex, Osaka, Japan). SRSi, $\mathrm{SRP}, \mathrm{NH}_{4}-\mathrm{N}, \mathrm{NO}_{2}-\mathrm{N}$, and $\mathrm{NO}_{3}-\mathrm{N}$ were colorimetrically determined using an autoanalyzer (AACS-II: Bran + Luebbe, Tokyo, Japan). 